\title{
Analysis of China's Strategies for Containing Coronavirus
}

\begin{abstract}
Yuhan Wang
Bishop Strachan School, Toronto ON M4V 1X2, Canada

Email: supervianna214@gmail.com

ABSTRACT

All countries have been affected by the COVID-19, causing financial stagnation. This paper analyzed the effect of Coronavirus on the economy and China's strategies to handle it. By researching and analyzing data from past to present, the passage evaluates China's financial status during COVID-19 and finds that China is greatly affected by the epidemic, but its measures in containing COVID-19 and handling an economic crisis have achieved some results. Analyzing China's strategy to fight the virus, we can conclude that China has a complicated domestic environment, and it makes the strategy based on it. Through the cooperation between the government and citizens, the Coronavirus crisis was properly handled.
\end{abstract}

Keywords: COVID-19, Chinese stock market, Financial problems, Solution to Economic recession

\section{INTRODUCTION}

COVID-19, nowadays, becomes one of the hottest issues around the world. This pandemic hits the global economy dramatically, having an enormous impact on our lives. Some existing articles discuss coronavirus implements in each country, but there is rarely an article that analyzes a country specifically. Therefore, this study aims to examine the pros and cons of how China dealt with coronavirus's financial and economic problems. This paper also intends to deepen the understanding of how effectively the measures are implemented when they work with the judgement on the economic and social environment.

\section{ANALYSIS}

\subsection{Containing COVID-19 Outbreak}

\subsubsection{Statistics}

China has accumulated 96,975 confirmed cases and 4,792 deaths up till January 4, 2021, in which the total confirmed cases is approximately $0.0069 \%$ of the total population, 1,401,780,182. Meanwhile, the accumulated cured patients are 90,851 , which is nearly $94 \%$ of the recovery rate. [1]

\subsubsection{China has learned from previous experience of $S A R S$}

2.1.2.1. Government: The initial outbreak of COVID19 occurred in late December, and the Chinese government's initial response was relatively slow when new cases did not confirm as coronavirus. However, from mid-January onwards, the Chinese government's response was swift and decisive after diagnosing confirmed cases were coronavirus. The prompt and accurate response was crucial to China's success towards containing COVID-19.

Considering how to contain the outbreak drawn from former experience, severe acute respiratory syndrome (SARS) outbreak in 2003, the Chinese government can now make more expeditious and instantaneous decisions than before. By timely isolating the patients with symptoms, rigidly enforcing quarantine of all contacts, and interrupting all kinds of human interaction, the Chinese government virtually exterminated the SARS. Unlike SARS, the COVID-19 is more contagious but less deadly. Nevertheless, the COVID-19 shares stunningly similar traits with SARS; therefore, by implementing similar strategies and propositions, even the Chinese government can't fully control the outbreak of COVID19 , but they can minimize peak incidence and worldwide fatalities. 
2.1.2.2. Citizens: Chinese citizens remember how severely the SARS-virus impacted their life, and that makes them obedient to the government's implementation when the pandemic is surging and prevalent "The society was vigilant as to what can happen in a coronavirus outbreak," said Xi Chen (Yale School of Public Health, New Haven, Connecticut, USA). "Other countries do not have such fresh memories of a pandemic."

Chinese citizen's high collaboration is a crucial factor contributing to the success of containing COVID-19. Public cooperation can be demonstrated explicitly by actively responding to the government's summons; for instance, even though each household is highly restricted to outdoor activities, they can only go out buying necessities and groceries. Likewise, people have high obedience to wear masks and implement self-isolation during the surge of COVID-19, even if they have to stay away from their family during the Chinese New Year, the time Chinese celebrate their family reunion.

From the cultural background, collectivism also plays an important role. Collectivism is a value characterized by an emphasis on cohesiveness among individuals and prioritization of the group over the self. Hence, to some extent, China's success in minimizing the disease's consequence is primarily due to public solidarity.

\subsection{Raising Economic and Financial Problems due to COVID-19}

\subsubsection{Overview}

China exterminated the COVID-19 cases as quickly as possible, even though the virus might have a tremendous impact on the economy in the short term, but once the situation gets better, the economy will recover sooner or later. If the government took longer to recover COVID-19 cases and alleviate the impact of economic crush in short in the short term, it would have stretched the lasting pandemic period longer and may cause more adverse effects on the economy. Fortunately, China avoided second or third waves, so the market's economic pressure has not further intensified.

\subsubsection{Stock Market Crash}

According to the graphs below, the stock market was affected much by the COVID-19 but sooner recovered. The graph represents the Shanghai Composite Stock Market Index, and the red circle indicates the stock market crash due to the start of COVID-19. It is reasonable to conclude that the stock market collapse awfully but almost recovered in March, and the index went up to the highest point than ever before after a few months.

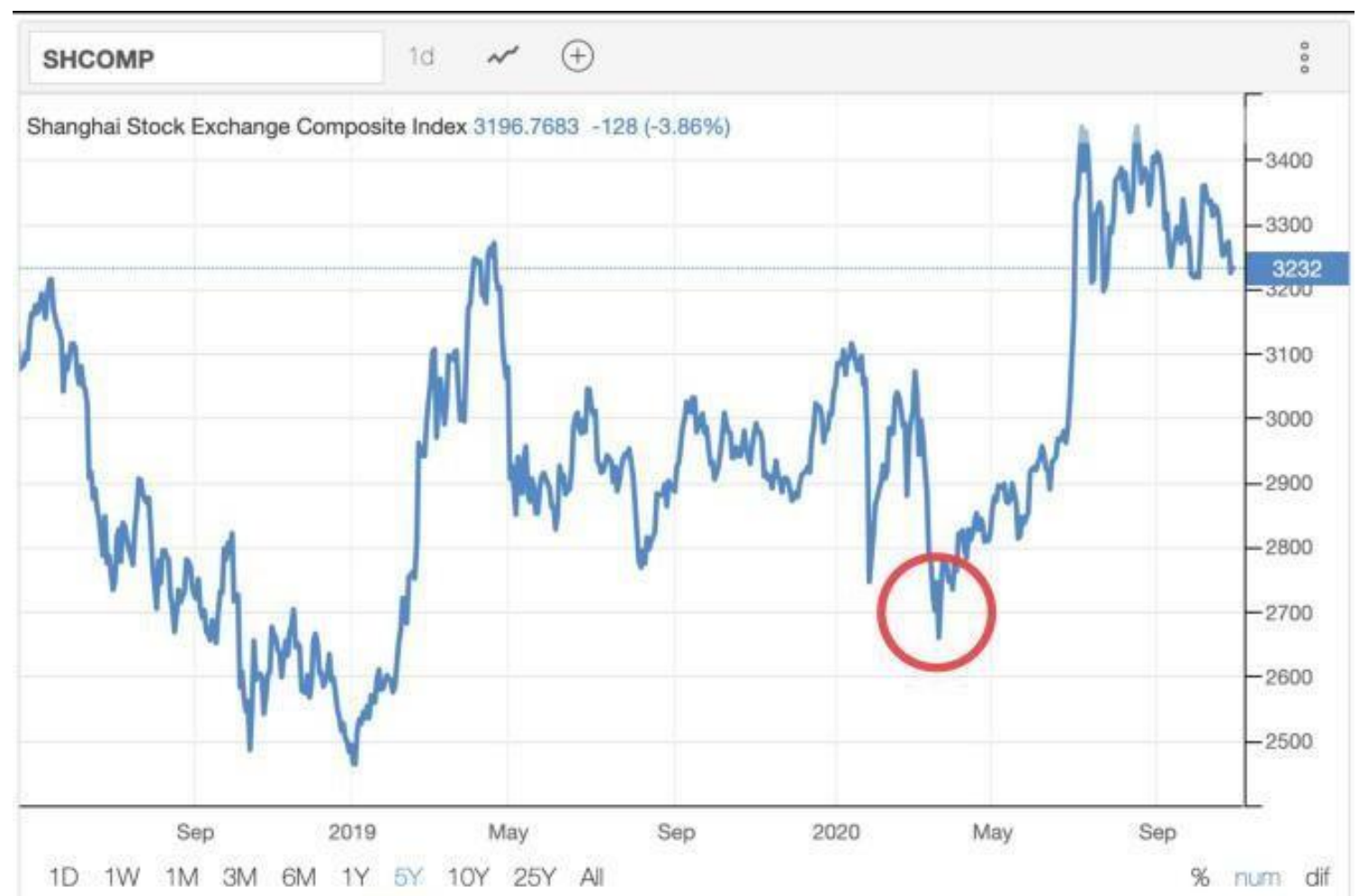

Figure 1 Chinese Stock Market [2] 


\subsubsection{Possible Reasons}

2.2.3.1. Economic intervention. One of the most significant advantages for economic intervention is to keep the unemployment rate relatively low. The government can force all its citizens and firms to stop working face-to-face and stay home during the pandemic. Businesses in the service industry, such as bars, restaurants, hotels, airlines, and other entertainment venues, are affected the most by the COVID-19, while other sectors are stagnated. Facing financial dilemmas, the company has to lay off employees, which suddenly boost the unemployment rate. Reporting by BBC News, most developed countries all have increased their yearly unemployment rate from 2019 to 2020, illustrated in Figure 2 below.

Yearly unemployment rate change, 2019-2020

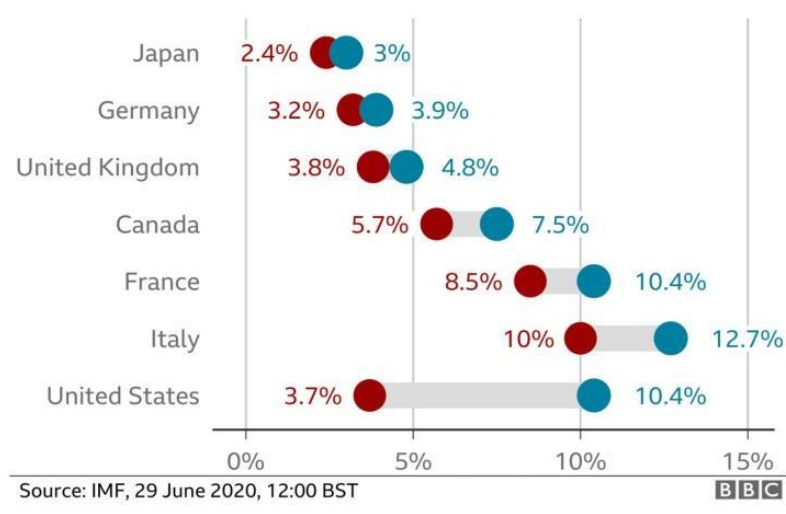

Figure 2 World economies struggling with rising unemployment [3]

Moreover, the LinkedIn hiring rate of all countries except China have sharp declines from February to MidApril when COVID-19 was surging and remains low steadily for the following months. By contrast, China has a sudden decrease since February but recovers shortly and exhibits a steady inclining trend, which ultimately exceeded the previous hiring rate even before the pandemic started.
Year-on-year percentage change

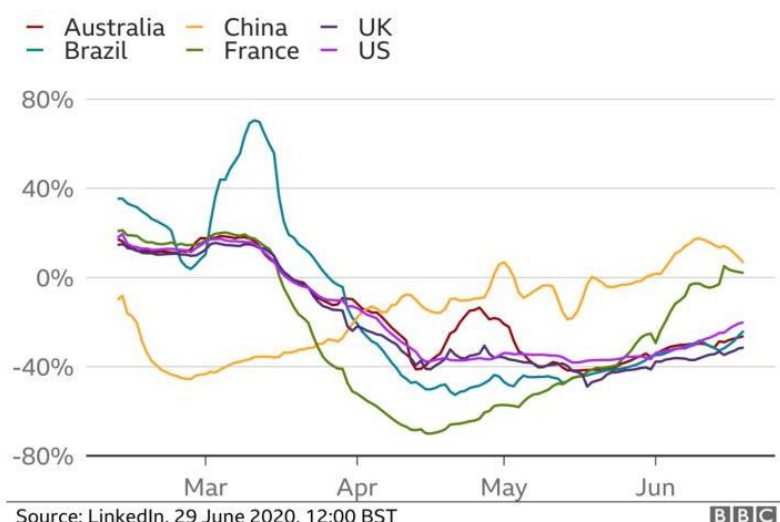

Figure 3 LinkedIn hiring rate by country [3]

The phenomenon can be explained by the discrepancy between government control and the financial system that each country exhibits. Despite incurring moral hazard and incapability to promote high working incentives among employees and firms, the Chinese government can provide jobs to the unemployed and rescue bankrupt companies, especially facing the economic recession. The Chinese government owns most production factors, such as land, capital, and resources; therefore, they are more authorized to wisely relocate resources while keeping jobs open to the people, which has the dominant influence on reducing the unemployment rate.

\subsubsection{Reducing the reliance on trade as a source} of growth: China is comparably less dependent on international trade in recent years. However, China is constantly deemed one of the world's largest exporting countries and predominantly relies on global trades and investments. In fact, the CNBC news article states that "China's economy has been reducing its reliance on trade as a source of growth" [4]; undoubtedly, domestic consumption has become the primary factor in supporting China's economic growth, meaning that manufacturers in the country are selling more to Chinese consumers, and less to the world (including France, Germany, India, Japan, United Kingdom, and the United States). Supported by the data below, China decreases its exposure to the world while gaining more World exposure. The study finds that China's net trade - the value of total exports minus that of imports - "actually made a negative contribution" to growth in recent years. Thus, it is reasonable to conclude that China's economy has been less dependent on trade but more on domestic consumers to boost growth. 


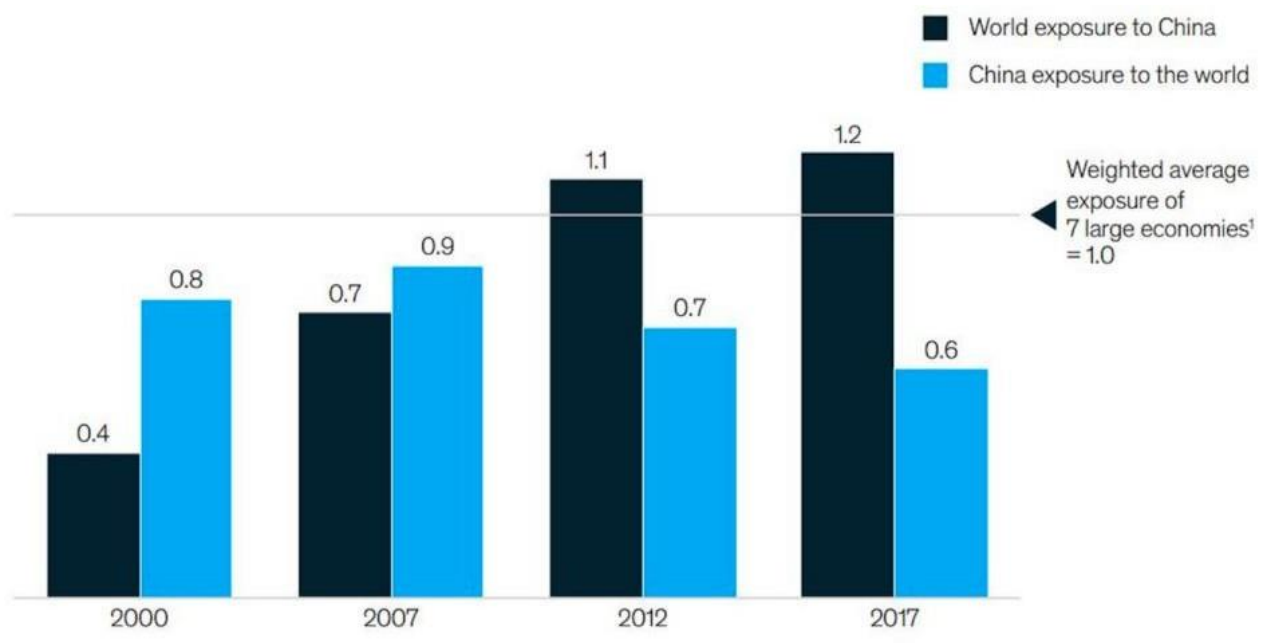

Figure 4 China-world exposure index [4]

During COVID-19, China is benefiting from its stable self-reliance of production demand. Although the economic recession hits the world due to COVID-19, China can resist financial crises and will not be affected as much due to a few financial links.

\subsubsection{Stable production demand: For China, the} steady demand for production is crucial in handling the financial downturn. The advantage of possessing a hyperscale economy demand has remained from past years, which backs up China in providing material logistics for emergencies. In 2019, China's economic aggregate was close to 100 trillion CNY, and per capita GDP exceeds 10,000 US dollars. The output of major industrial products has remained the world's largest for many years. Despite the severe impact of the outbreak from January to February this year, the primary production indexes' scale and volume are impressive. The overall output value of industries exceeding designated size reached 11.5 trillion CNY from January to February. The gross retail sales of manufactured goods surpassed 5.2 trillion CNY, and fixed assets' investments exceeded 3.3 trillion CNY. [5]

\subsubsection{Support for emergency supply system: China} sustains substantial economic resilience for production. From a general viewpoint, the industry has not been affected much by this economic stagnation. Nevertheless, some sectors have maintained relatively strong growth. From January to February, ethylene output increased by $5.6 \%$ in terms of product output, crude steel, and pig iron output increased by $3.1 \%$. The output of ten non-ferrous metals increased by $2.2 \%$.

During the pandemic, a shortage of supplies would be the primary concern. Society's demand for disinfection products such as masks, surgical gowns, and alcohol has risen sharply. To meet the massive demand for emergency equipment and supplies, China has to mass-produce the relevant products in a short period. Xinhuanet, one of the most influential online News media in China, states that
China's daily mask output exceeds 110 million units,[6] proving that China has a substantial supply capacity for handling COVID-19 and future emergencies.

\subsubsection{Strong Internet Economy is well-developed:}

The Internet plays such an essential role during the COVID-19, significantly if people are restricted to outdoor activities. It is vital, especially or supplies allocation, grocery delivery, online education, and cultural entertainment. The advanced technology ensures necessities are delivered as quickly as possible to receive their food on the same day they ordered. Overall, the internet economy has done relatively well in all countries, and state-of-the-art technology enables people's lives to be more convenient.

\subsection{Solutions to the Economic Recession}

China lowers interest rates and hands out stimulus packages to help alleviate the economic recession due to COVID-19. The Chinese central bank, the People's Bank of China, cuts the one-year loan prime rate from $4.15 \%$ to $4.05 \%$, and the five-year rate from $4.80 \%$ to $4.75 \%$ [7].

China pledges economic rescue packages to save jobs and livelihoods amid coronavirus. The stimulus package includes 4 trillion yuan (US\$559 billion) worth of cost cuts aiding local factories and enterprises. Li Keqiang, China's Premier, states that "ensuring employment, people's livelihoods and [helping] market entities" are the prime purposes of this stimulus package[8]. The stimulus package is designed in two ways: people with lower wages and desperately need financial aid to maintain daily survival. Secondly, it functions like surefire investments to stimulate the country's economic growth and eliminate the financial recession[9].

\section{CONCLUSION}

COVID-19 happened suddenly and unknowingly, panicking everyone, and we should have developed preventive measures in advance. It is a critical lesson for 
us to learn, and it can also be an excellent opportunity for having this precious experience to prevent similar foreseeable catastrophes from happening. Although China does an impressive job handling COVID-19, there still are areas for improvement. The circumstance changes when this article is written so that the data may vary from time to time. The government might introduce brand new policies and implement measures in the future that are not covered in the article. Plus, due to limited research sources, this paper might not comprehensively summarize and discover all the strategies China took in dealing with the Coronavirus. Further studies are needed to back up the thesis, focusing on future vaccine development, to draw a more accurate and thorough conclusion.

\section{ACKNOWLEDGMENTS}

First and foremost, I would like to express my sincere gratitude to my teachers and professors, who have inspired me to explore possible ideas for thesis and subargument. Besides, I would like to thank my friends for their support. I could not have accomplished my essay without all their enlightening instruction and impressive goodness.

\section{REFERENCES}

[1] Live Update: COVID-19 Cases. (2021, January 4). Retrieved January 04, 2021, from https://voice.baidu.com/act/newpneumonia/newpne u monia/?from=osari_pc_3\#tab4

[2] China Shanghai Composite Stock Market Index1990- 2020 Data: 2021-2022 Forecast. (n.d.). Retrieved November 03, 2020, from https://tradingeconomics.com/china/stock-market

[3] L. Jones, D. Palumbo \& D. Brown, 2020, Coronavirus: A Visual Guide to the Economic Impact https://www.bbc.com/news/business51706225

[4] Y._Lee. (2019, July 22). McKinsey research finds the world becoming more exposed to China -but not the reverse. Retrieved November 03, 2020, from https://www.cnbc.com/2019/07/15/mckinsey- worldhas-become-more-exposed-to-china-but-not- thereverse.html

[5] Spokesperson, from National Bureau of Statistics of the People's Republic of China, answers reporters' questions on the operation of the national economy from January to February 2020. Retrieved November 03, 2020, from http://www.stats.gov.cn/tjsj/sjjd/202003/t20200316 _ 1732372.html

[6] China's daily mask output exceeds 110 million units. (n.d.). Retrieved November 03, 2020, from http:/www.xinhuanet.com/english/202003/02/c_138835152_2.htm

[7] Y._Lee. (2020, February 20). China cuts benchmark lending rates amid coronavirus outbreak. Retrieved November 03, 2020, from https://www.cnbc.com/2020/02/20/coronaviruschinas-pboc-cuts-benchmark-lending-rate-loanprime-rate.html

[8] China pledges largest-ever economic rescue package to offset virus damage. (2020, May 29). Retrieved November 03, 2020, from https://www.scmp.com/economy/chinaeconomy/article/3086569/china-pledges-largestever- economic-rescue-package-save-jobs

[9] T. Law. (2020, August 27). U.S. Stimulus Package 2020: Everything You Need to Know. Retrieved November 03, 2020, from https://www.oberlo.ca/blog/us-stimulus-package 